\title{
Euthanasia and Physician-Assisted Suicide: A Review from Islamic Point of View
}

\author{
Yousuf RM, Mohammed Fauzi AR \\ Department of Internal Medicine, Faculty of Medicine, International Islamic University Malaysia
}

\begin{abstract}
Due to globalizing trend of homogenisation of culture, changes in the health care delivery system and market economics infringing on the practice of medicine, there has been a gradual shift in the attitude of the medical community as well as the lay public towards greater acceptance of euthanasia as an option for terminally ill and dying patients. Physicians in developing countries come across situations where such issues are raised with increasing frequency. As the subject has gained worldwide prominence, we want to review this topic from Islamic perspective due to its significance in medical ethics and clinical practice.
\end{abstract}

KEYWORDS: euthanasia, ethics, legalisation, withholding/withdrawing of treatment, Islam

\section{INTRODUCTION}

With advances in modern medicine, people live longer and the number of elderly people is increasing. As a result, the ethical issues surrounding end of life care continue to gain importance. Proponents of active euthanasia believe prolonged death in a medical setting is unnatural and undignified and therefore advocate "death with dignity" by assisted suicide as a humane end-of-life care. ${ }^{1}$ The term euthanasia or mercykilling is defined as a deliberateact, undertaken by a physician, to end the life of a person at his request in the name of compassion. ${ }^{2,3}$ The physician therefore administers the lethal substance. In physician-assisted suicide (PAS), physician supplies the means, usually medications to a patient who then takes necessary action to end his life. ${ }^{4}$ Euthanasia is a general term that actually means different things depending upon the context in which it is used. There is a distinction between voluntary (when the patient has expressed a wish to die and another individual assists his death by performing the act of euthanasia), non-voluntary (when a patient is comatose or lacks decisional-capacity e.g. mentally retarded or unable to express their own wishes, i.e. babies) and involuntary euthanasia when a patient with decisional capacity is not consulted or his surrogate refuses yet his life is ended. ${ }^{5,6}$ Passive euthanasia refers to the practice of withdrawing or refraining from be-

Corresponding author:

Mohammad Yousuf Rathor, MD

Associate Professor

Department of Internal Medicine,

Faculty of Medicine,

Jalan Hospital Campus,

International Islamic University Malaysia

27510 Kuantan, Pahang, Malaysia

Phone (o): 09-5132797

Fax: 609-5177631 ginning some type of medical intervention among terminally ill patients. For example, withdrawing treatment thathasbeenshowntobefutileorterminating life-sustaining equipment, such as ventilators when there is no chance of recovery. This doctrine seems to be accepted by most physicians, and it is endorsed by American Medical Association opinion 2.211, 1994. The reason in this instance is that delaying the inevitable death through life-sustaining measures is neither in the patient's best interests nor the public's. Similarly, administering opiates that may endanger life (so-called indirect euthanasia) are deemed ethical as long as the intention is pain relief. ${ }^{7-9}$ Unfortunately, the above definitions which come from the Western bioethics have crept up in Islamic discussions on bioethical issues. Therefore, Islamic writings deliberate on euthanasia by using the same categories as set by the Western bioethics. The terms "passive" euthanasia and "indirect" euthanasia are not really types of euthanasia as there is no intention to take life of the patient and should be discarded. They only confuse the public and make them unwilling to take appropriate palliative care. They are part of good medical practice, endorsed by law, when they are properly carried out. ${ }^{9}$ Proponents of euthanasia maintain that, allowing a patient to die is to exercise his autonomy by ending sufferings beyond endurance. Islamic jurisprudence acknowledges autonomy as stipulated by the assertion that no one is entitled to dispose of the right of a human being without his permission. ${ }^{10}$ Autonomy is important in the decisionmaking process if patients are able to understand and makeintelligent decisions. Further, itmustbeexercised within certain limits and in conjunction with responsibilities towards others. Euthanasia is not primarily an individual issue; rather a societal one. Ethical decision must balance the rights of the individual, views of the society as a whole and the desires and wishes of the family or those close to him. An individual's freedom of choice is constrained by the harm it causes others. The literature review suggests that uncontrolled pain was not a major 
determinant of interest in euthanasia; rather it was depression, loneliness, hopelessness, and general psychologicaldistress. ${ }^{11-13}$ It isnevercertain thatapatient voluntarily consents to death, as this desire frequently changes over time, especially if pain and depression are treated. The exercise of autonomy therefore, cannot include the ending of one's life because that would mean ending the possibility of exercising autonomy. It would be morally justifiable for physicians to apply guided paternalism and prevent such patients from harm undertheprincipleofbeneficenceandnon-malfeasance.

The issue of euthanasia and PAS (EAS) has been debated all over the world, and attempts to legalize it have been defeated most of the times. ${ }^{14}$ The controversy regarding its practice is essentially a controversy about ethics and morality. Several studies have evaluated the attitudes of health care professionals and general public towards euthanasia. ${ }^{15-17}$ Data from these studies has shown that internationally public opinion tends to favour its legalisation than medical opinion. A study from Asia revealed that almost all physicians disapproved EAS, but favoured withholding or withdrawing futile treatment..$^{18}$ A recent study (2011) conducted in Malaysia among physicians and chronically ill patients about euthanasia and related issues revealed that vast majority of respondents opposed EAS, no matter what the circumstances may be, but overwhelmingly agreed withholding or discontinuing futile treatment/artificial life support to a patient with no chances of survival. ${ }^{19}$ The study also found that religion was the most consistent factor in shaping the respondent's attitude towards EAS.

At present EAS is illegal in most of the world, but a few countries have passed laws in its favour. Legalisation of EAS through referendums will have major clinical implications and its worst victims would be the elderly, mentally-retarded, AIDS and cancer patients, the disabled and even children and newborn with disabilities. ${ }^{20}$ Under current prevailing conditions the practice of medicine must not be guided by economic and political forces, but by ethics that is internal to the medicine. In an attempt to facilitate understanding, we intend to review this topic from Islamic perspective.

\section{Religions' Viewpoints}

Most religions uphold the sanctity of human life and disapprove EAS, while some absolutely forbid it. A number of studies have revealed that religious beliefs are the main predictors of opposition to EAS among general population. ${ }^{21-23} \mathrm{~A}$ relationship between religious activity and a restrictive attitude towards euthanasia has also been documented both for physicians and other health care personnel. ${ }^{24}$ Most moral people recognize it as a form of murder, regardless of the alleged merciful motives. ${ }^{25}$ The followers of Hinduism, Buddhism and Jainism Volume 11 Number 1 June 2012 regard euthanasia as unacceptable. ${ }^{26}$ All monotheistic religions Judaism, Christianity and Islam view EAS as crimes, just like any other murders. They all believe that human life is a gift from God, and no human being should get rid of such a gift. ${ }^{27}$ Islam, like other religions upholds the sanctity of life. Islam is not just a religion in the contemporary understanding, but rather a way of life that encompasses all aspects of life and secures guidance and light for all mankind. Bioethical decision making is carried out within a framework of values derived from three sources of sacred law. The first is the Qur'an, the word of Allah (s.w.t.) which encompasses all facets of human life. The second is the Sunnah, the sayings and traditions of Prophet Muhammad. The third is ijtihād, the concerted effort and study of Islamic principles to derive legal opinions from the law, to a particular situation. ${ }^{28}$ Religion defines the role of the individual, the family, and the physician in all spheres of life including birth, illness, and death. In Islam, saving of life is a duty, and the unwarranted taking of life a grave sin, as emphatically stated in various verses of the Holy Qur'an. "Do not kill yourselves for verily Allah has been to you most Merciful" (Qur'an 4:29). "Do not take life which God has made sacred except in the course of Justice" (Qur'an 17.33) and "anyone who has killed a fellow human except in lieu of murder or mischief on earth, it would be as he slew the whole mankind"(Qur'an 5:32). As is evident from these verses, the saving of a life is considered one of the highest merits and imperatives in Islam. Allah (s.w.t.) states that if anyone saves one life, it is equivalent to saving the lives of the whole mankind and if one takes life unjustly, it equates to the killing of entire mankind. Therefore it legitimizes us for research and medical advances for saving human lives and justifies the prohibition of EAS. ${ }^{29}$ Suicide is not only forbidden but one who contemplates such an act is warned of a grievous punishment. "And whoever commits that (suicide) through aggression and injustice, We shall cast him into the Fire, and that is easy for Allah" (Qur'an 4:30). The Qur'an also prohibits consenting to one's own destruction and it could be related to those terminally ill patients who give consent to mercy killing. "And spend in the cause of Allah and do not throw yourselves into destruction and do good. Truly, Allah loves the good-doers" (Qur'an $2: 195)$. In a similar way, Islam prohibits any help in conducting sinful acts: "And do not help each other in sin and aggression" (Qur'an 5:2). In light of these verses active euthanasia is prohibited and killing an innocent human being is one of the major sins in Islam. Committing a prohibited act brings penalties and omitting it brings great reward. The physician will be held responsible for his actions and cannot claim that he was acting on the patient's instructions.

Life is a great gift from Allah (s.w.t.) and is to be cherished and protected at all times. Prophet Muhammad has said: "Do not harm yourself or others"(reported by Ahmad and Ibn Majah). So we 
need to promote whatever benefits the individual and the community and abolish whatever works against their benefit. Prophet also approved the principle of medical treatment and has encouraged us to seek it. In an authentic hadith, he is quoted as saying: "O, servants of Allah, seek treatment, for Allah has not sent down any illness without sending down its treatment." 30 Islam encourages medication; but, once medication is seemingly futile; refusing, withholding, withdrawing and discontinuing such medication is allowed. While Islam gives importance to saving life, it also makes it clear that death is inevitable, part of human contract with Allah (s.w.t.) and part of the journey on this planet. "Every soul will have a taste of death. In the end, to us, shall you be brought back" (Qur'an 29:57). "Everyone shall taste death. And only on the day of resurrection shall you be paid your wages in full. And whoever is removed away from the fire and admitted to paradise, this person is indeed successful. The life of this world is only the enjoyment of deception" (Qur'an 3:185). "Nor does anyone know what it is that he will earn tomorrow: Nor does anyone know in what land he is to die. Verily with Allah is full knowledge and Allah is acquainted with all things "(Qur'an 31: 34). The life and death are the prerogatives of Allah (s.w.t.) as categorically stated in the Qur'an: "Blessed is He, in Whose Hands is the Sovereignty, and He is able to all things. Who has created death and life that He may test you, which of you is best in conduct and $\mathrm{He}$ is the Mighty and the Forgiving"(Qur'an 67: 1-2). Death does not happen except by Allah's permission, as dictated in the Qur'an: "it is not given to any soul to die, but with the permission of Allah at an appointed time"(Qur'an 3:145). Muslims believe that Allah (s.w.t.) is the Creator and the Owner of all life and only He will end it through natural death. "Allah gives life and death, and Allah sees well all that you do"(Qur'an 3:156). One may safely infer from this verse that if a physician increases dosage of painful medication, being fully aware that this would in effect cause death of the patient, he would then be held liable for terminating the life of his patient, which equates to murder under the shari $a$. The intention of the physician may not be known to anybody else, but his intention cannot escape the ever-watchful supervision of Allah (s.w.t.) as the Qur'an states: "[Allah] knows the treachery of the eyes and what the hearts conceal"(Qur'an 40: 19). Prophet Muhammad has absolutely refused to bless the body of a person who had committed suicide. $\mathrm{He}$ is reported to have said: "Let no Muslim die except expecting and hoping the best from Allah" (reported by Muslim). In view of these hadith, Islam categorically forbids all forms of suicide and euthanasia as it negates ones belief in Allah's (s.w.t.) absolute mercy by taking the decision, regarding the termination of life in our own hands. Thus, Qur'an emphasizes that "it is the sole prerogative of Allah to bestow life and to cause death", and therefore euthanasia is never allowed. ${ }^{31,32}$ According to the International Islamic Code for Medical and Health Ethics (article sixty-one) every act on the part of Volume 11 Number 1 June 2012 physician which involves killing of terminally ill patient, or any assistance or guidance in killing is prohibited in Islam. ${ }^{33}$ In a similar way, Muslim scholars have categorically voiced against EAS. For example, the renowned Egyptian scholar Sheikh Yusuf al-Qaradawi has issued a fatwa, or religious edict, equating euthanasia with murder, but allowing the withholding of treatment that is deemed useless. He has made the following statement: "This act [euthanasia] is islamically forbidden for it encompasses a positive role on the part of the physician to end the life of the patient and hasten his death via lethal injection, electric shock, a sharp weapon or any other way. This is an act of killing, and, killing is a major sin and thus forbidden in Islam, the religion of pure mercy". ${ }^{34}$

Justification of taking life to escape suffering is not acceptable in Islam. A Muslim is not supposed to become hopeless nor feel panic when afflicted with any sickness because of his belief in Allah's (s.w.t.) absolute mercy, his faith in destiny and his belief in the Hereafter. The Qur'an points out that the believers will be put to the test in various ways, to confirm a believer's spiritual station: "Be sure that We shall test you with something of fear and hunger, some loss in goods or lives or the fruits of your toil, but give glad tidings to those who patiently persevere" (Qur'an 2:155). The suffering as a result of disease does not rob him of his dignity, but rather benefits him spiritually. Every moment whether in pain or relief, brings opportunities for a Muslim to mend his eternal life. However, he is supposed to seek treatment in response to the Prophet's order to seek medical treatment and a Muslim physician is ordained to help alleviate suffering. ${ }^{35}$ Allah (s.w.t.) says: "And who despairs of the mercy of his Lord, but those who are misguided "(Quran 15:56). This life is only a precursor to a better life after death (Akhirah) for believers. There is still another dimension to the question of pain and suffering. Patience and enjoining forbearance are highly regarded and highly rewarded values in Islam. "Those who patiently preserve will truly receive a reward without measure" (Qur'an 39:10). "And bear in patience whatever (ill) maybe fall you: this, behold, is something to set one's heart upon" (Qur'an 31:17). Prophet Muhammad has said "When the believer is afflicted with pain, even that of a prick of a thorn or more, God forgives his sins, and his wrongdoings are discarded as a tree sheds off its leaves." According to a hadith of Prophet "There was a man in older times with an ailment that taxed his endurance, so he took a knife, cut his wrist and bled to death. Upon this God was displeased and said: My subject hastened his end, I deny him paradise" (Hadith: Bukhari 8:603). In a second hadith "he who commits suicide by stabbing himself will continue to stab himself in hell (for eternity). ${ }^{36} \mathrm{~A}$ third hadith recalls the case of a warrior during a military campaign who got killed and the companions of the prophet kept praising his gallantry and efficiency in fighting, but to their surprise, the Prophet commented, "His lot is hell." Upon inquiry, the 
companions found out that the man had been seriously injured so he supported the handle of his sword on the ground and plunged his chest onto its tip, committing suicide (Hadith: Bukhari 23: 446). From these hadith we gather that while voluntary euthanasia may end the suffering of a patient in this world, his problem would be further compounded in the hereafter by being excluded from inheriting a place in Paradise. Likewise, Grand Mufti of Egypt Ali Gomaa responding to the question: What is the ruling in Islam for euthanasia, meaning: where the patient asks the doctor to terminate his life because of excruciating pain or disability; or where the doctor himself decides that it is better for the patient to die than to live in pain or disabled?" He responds by stating that euthanasia in its two forms described in the question is not permissible. It is incumbent upon physicians to know that there is no obedience to other people in a matter that constitutes disobedience to Allah (s.w.t.). Whenevera patient asks this of them, they must not accede, nor [are they to] kill another person without right. As for a physician terminating the life of a patient for a reason he personally deems justifiable: it is the unlawful taking of human life. ${ }^{37}$ The IMA (Islamic Medical Association) endorses thestand that there is noplace for euthanasiain medical management, under whatever name or form (e.g., mercy killing, suicide, assisted suicide, the right to die, the duty to die, etc.). Nor does it believe in the concept of a wilful and free consent in this area. The Islamic Code of Medical Ethics endorsed by the First International Conference on Islamic Medicine (Islamic Organization of Medical Sciences, Kuwait, 1981, p.65) includes: "Mercy killing, like suicide, finds no support except in the atheistic way of thinking that believes that our life on this earth is followed by void. The claim of killing for painful hopeless illness is also refuted, for there is no human pain that cannotbelargelyconqueredbymedication orbysuitable neurosurgery." ${ }^{38}$ Suicidal thoughts are known to occur in a person when he or she has lost all hope in life and is in extreme despair. The literature review suggests that uncontrolled pain was not a major determinant of interest in EAS; rather it was depression, hopelessness, and general psychological distress. ${ }^{39-41}$ This desire frequently changes over time, especially if pain and depression are treated. Further patients may be subjected to external pressures from healthcare providers, insurers and relatives who do not want to support them through their illness or want to minimise costs while internal pressures may originate from within the patients themselves, who may perceive themselves as worth less, burden to their families and caregivers. In an environment where euthanasia is a legal and a legitimate option, it is already pressure enough on the patient, who would correctly or incorrectly, read in the eyes of his family/caregivers the silent appeal to go that causes him to accept EAS. In contrast Islam provides a cohesive social system and set of rules which keeps community of believers in warm relationships with each other, thus providing an atmosphere in which individuals are morally, emotionally and even physically supported. Dignity is not a concept that can Volume 11 Number 1 June 2012 be forfeited, so being dependent on others cannot cause one to lose his dignity. Human dignity can be restored through caring for each other and by providing a suitable psychological support in times of dependence and need. The holy Qur'an tells us to be good to parents and everyone else who you meet. "Serve God, and join not any partners with Him; and do good-to parents, kinsfolk, orphans, those in need, neighbors who are near, neighbors' who are strangers, the companion by your side, the wayfarer (ye meet), and what your right hands possess: For God loveth not the arrogant, the vainglorious" (Qur'an 4:36). Family obligations are considered a moral injunction from Allah (s.w.t.). Islam demands aging parents in particular to be treated with patience and humility. ${ }^{42}$ Regarding elderly parents, the Qur'an states: “And your Lord has decreed that you shall not worship except Him and honour your parents, for as long as they live, one of them or both of them, you shall not speak harshly to them or mistreat them; you shall speak to them amicably. And lower for them the wings of humility and kindness and say: My Lord, have mercy on them for they brought me up from infancy" (Qur'an 17:2324). "And We have enjoined on man (to be good) to his parents. In travail upon travail helpless did his mother bear him, and in two years was his weaning. Show gratitude to Me and to thy parents; to Me is thy final goal" (Qur'an 31: 14). According to the above verse, gratitude to Allah (s.w.t.) and to parents goes hand in hand. Gratitude to Allah (s.w.t.) is incomplete without showing gratitude to one's parents. Since being grateful to Allah (s.w.t.) is a form of worship which earns heavenly rewards, it can therefore be said that being grateful to one's parents also earns heavenly rewards. Further the reverence and consideration afforded to the elderly is evident in the manner our Prophet has instructed us when dealing with our parents and the elderly. He has said, "The best beloved of Allah (s.w.t.) is one who loves his family the most". ${ }^{42}$ Abu Huraira reported Prophet Muhammad as saying: "Let him be humbled into dust; let him be humbled into dust. It was said: God's Messenger, who is he? He said: He who sees either of his parents during their old age or he sees both of them, but he does not enter Paradise (because he has been undutiful to them)"(Muslim). Mothers are particularly honoured as expressed in saying of the Prophet: "jannat (paradise) lies under the feet of a mother". If these notions are understood, a Muslim would never contemplate EAS.

In terminally ill patients, when the hope for a cure is gone, physicians must reframe the patient and family's hope for something more realistic and achievable by providing palliative care focused on relieving symptoms, holistic care and allowing natural death to take place. This may be carried out at home or in an institution as the case warrants. Prophet Muhammad gave his followers the following advice: "None of you should wish for death because of a calamity befalling him; but if he has to wish for death he should say: 'O Allah! Keep me alive as long 
as life is better for me and let me die if death is better for me." The best hospice for a Muslim is to die at home with family members around. Natural death is in the patient's best interests and is the most dignified death for a Muslim believer.

When the physicians are certain about the inevitability of death, cessation of medical treatment thought to be useless and futile (including the respirator) is permissible and sometimes even recommended for the sake of the patient's comfort and the relief of his family, allowing death to take its natural course. ${ }^{31,32,43}$ However, it should be a collective decision taken on the basis of informed consent, following a discussion between medical experts and the patient's family, but it is never permissible to take any direct action designed to kill the patient. Withdrawal of food and drink is not allowed. This also applies to patients in a persistent vegetative state. ${ }^{31}$ Physicians and the family should realize the limitations of medical technology. According to a scholar from Saudi Arabia, a fatwa has been issued in that country that if the treating physicians decide that resuscitation will be useless in a certain patient, it is permissible not to resuscitateeventhough thepatientorhisrelativesaskfor resuscitative measures to be carried out. It is a medical decision and not in their capacity to decide. ${ }^{44}$ Accepting divine providence also involves accepting death as part of Allah's (s.w.t.) plan. Indeed, after death a better and higher existence awaits believers.

\section{CONCLUSION}

Voluntary euthanasia/suicide is strongly abhorred and outlawed in Islam, that its punishment is eternal hell. Since Islam is a global religion, care givers should have an insight into the various religious and ethnic backgrounds pertaining to terminal illness and death. Muslim physicians must perceive themselves as being commissioned by Allah (s.w.t.) to reflect Islamic values in pursuit of their vocations by showing full respect and full protection for any life in accordance with Islamic teachings. We hope that this review will improve physicians' knowledge of the end-of-life care to the Muslim patients.

\section{REFERENCES}

1. Fernandes AK. Euthanasia, assisted suicide, and the philosophical anthropology of Karol Wojtyla. Christ Bioeth 2001;7:379-402.

2. Deliens L, van der Wal G. The euthanasia law in Belgium and the Netherlands. Lancet 2003; 362:1239-40.

3. Watson R. Luxembourg is to allow euthanasia. BMJ 2009;338:b1248.

4. Pickett J. "Can Legalisation Improve End-ofLife Care? An Empirical Analysis of the Results of the Legalisation of Euthanasia and Physician-Assisted Suicide in the Nether lands and Oregon." The Elder LJ 2009;16:333- 37.
5. Fok SY, Chong MLA, Tang KC. Attitudes of Acutely III Patients Towards Euthanasia in Hong Kong. Open Nurs J 2007;1:1-5.

6. Chao DVK, Chan NY, Chan WY. Euthanasia revisited. Fam Pract 2002;19:128-34.

7. Emanuel EJ. The history of euthanasia debates in the United States and Britain. Ann Intern Med 1994; 121:793-802.

8. Lo B, Rubenfeld G. Palliative sedation in dying patients: "we turn to it when everything else hasn't worked". JAMA 2005;294:1810-6.

9. Verkerk $M$, van Wijlick $E$, Legemaate J, de Graeff A. A National Guideline for Palliative Sedation in the Netherlands. J Pain Symptom Manage 2007;34:666-70.

10. Aksoy S, Elmali A. The core concept of the four principles of bioethics as found in Islam ic tradition. Med Law 2002;21:211-24.

11. van der Maas PJ, van der Wal G, Haverkate I, et al. Euthanasia, physician-assisted suicide, and other medical practices involving the end of life in the Netherlands, 1990-1995. N Engl J Med 1996;335:1699-705.

12. Emanuel EJ, Fairclough DL, Emanuel LL. Attitudes and desires related to euthanasia and physician-assisted suicide among terminally ill patients and their caregivers. JAMA 2000; 284:2460-68.

13. Wilson KG, Scott JF, Graham ID, et al. Attitudes of terminally ill patients toward euthanasia and physician-assisted suicide. Arch Intern Med 2000;160:2454-60.

14. Emanuel EJ - Euthanasia and PhysicianAssisted Suicide. A Review of the Empirical Data from the United States. Arch Intern Med 2002;162:142-52.

15. Seale C. Legalization of euthanasia or physician-assisted suicide: survey of doctors' attitudes. Palliat Med 2009;23:205-12.

16. Patelarou $\mathrm{E}$, Vardavas $\mathrm{Cl}$, Fioraki I,et al. Euthanasia in Greece: Greek nurses' involvement and beliefs. Int J Palliat Nurs 2009;15:242-8.

17. Inghelbrecht E, Bilsen J, Mortier F, Deliens L. Nurses' attitudes towards end-of-life decisions in medical practice: a nationwide study in Flanders, Belgium. Palliat Med 2009,23:649-58.

18. Pioneering NUS study unveils what Singapore doctors say about caring for the dying. Available at: www.lienfoundation.org/pdf/ news/. Accessed on Feb 20, 2012.

19. Yousuf RM, Fauzi ARM, Arif SM, et al. Attitudes towards euthanasia and physician-assisted suicide among physicians and patients in a multi-cultural society of Malaysia. In press.

20. J Pereira. Legalizing euthanasia or assisted suicide: the illusion of safeguards and controls. Curr Oncol 2011;18:e38-45.

21. Bachman JG, Alcser KH, Doukas DJ, et al. Attitudes of Michigan physicians and the 
public toward legalizing physician-assisted suicide and voluntary euthanasia. $\mathrm{N}$ Engl J Med 1996;334:303-9.

22. Suarez-Almazor M, Belzile M, Bruera E. Euthanasia and physician-assisted suicide: a comparative survey of physicians, terminally ill cancer patients, and the general population. J Clin Oncol 1997;15:418-27.

23. Ward RA. Age and acceptance of euthanasia. J Gerontol 1980;35:421-31.

24. Førde R, Aasland OG, Falkum E. The ethics of euthanasia - attitudes and practice among Norwegian physicians. Soc Sci Med 1997;45:887-92.

25. Beckwith FJ, Geisler NL. Matters of Life and Death. Grand Rapids. MI : Baker Book House, 1991: 142.

26. Coward HG, Lipner JJ, Young KK. Hindu Ethics : Purity, Abortion, and Euthanasia. New York: State University of New York 1989:71-121.

27. Engelhardt HT, Iltis AS. End-of-life: the traditional Christian view. Lancet 2005; 366:1045-9.

28. Dar AS, Khitamy A. Bioethics for clinicians. Islamic bioethics. CMAJ 2001;164:60-3.

29. Sachedina Islam. In: Reich WT, editor. Encyclopedia of bioethics. Rev ed. New York: Simon and Schuster/Prentice Hall Internationai 1995:1289-97.

30. Sunan Abi Dawuud. Vol. 2, Book 27, Kitab al-Tibb, Chapter 1, Hadith 3855. Available at: http://www.muhaddith.org.Accessed February 20, 2012.

31. Ebrahim AFH. The living will (Wasiyat AlHayy): a study of its legality in the light of Islamic jurisprudence. Med Law 2000;19: 147-60.

32. Sachedina A. End-of-life: the Islamic view. Lancet. 2005;366:774-9.

33. The Islamic Code for Medical and Health Ethics. In: Islamset site. Available at: http://www.islamset.com/ioms Code2004/ index.html. Accessed April 5, 2012.

34. Al-Qaradawi Y. Question and answer about Euthanasia. In: Islam online site. Available at: http://www. islamonline.net/servlet/ Satellite?cid $=1119503544774$ \&pagename $=$ Is lamOnline-English-Ask_Scholar/FatwaE/ FatwaEAskTheScholar. Accessed April 5, 2012.

35. Sachedina A. Right to die: Muslim views about end of life Decisions. Available at: http://www.people. virginia.edu/ aas/ar ticle/article3.htm. Accessed April 5,2006.

36. Hathout, Hassan. Islamic Basis for Biomedical Ethics. In: Transcultural Dimensions in Medical Ethics, Ed. Edmund D. Pellegrino, Patricia Mazzarella, and Pietro Corsi, 1992; 57-72.

37. Goma Ali. Ethics of Euthanasia. Available at:http://www.islamopediaonline.org/ fatwa/egypts-darul-ifta-euthanasia. Accessed April 5,2012.

38. The sanctity of human life. In: Islamic code of ethics. In Islamset site. Available at: http://www. islamset.com/ethics/ code/cont2.html. Accessed April 4, 2012.

39. van der Maas PJ, van der Wal G, Haverkate I, et al. Euthanasia, physician-assisted suicide, and other medical practices involving the end of life in the Netherlands, 1990-1995. N Engl J Med 1996; 335:1699705.

40. Emanuel EJ, Fairclough DL, Emanuel LL. Attitudes and desires related to euthanasia and physician-assisted suicide among terminally ill patients and their caregivers. JAMA 2000; 284:2460-68.

41. Wilson KG, Scott JF, Graham ID, et al. Attitudes of terminally ill patients toward euthanasia and physician-assisted suicide. Arch Intern Med 2000;160:2454-60.

42. F. Rehman, Health and medicine in the Islamic tradition. Chicago: $A B C$ International Group, 1998:30-1.

43. The Islamic Code for Medical and Health Ethics. In: Islamset site. Available at: http:// www.islamset.com/ioms/ Code2004/index.html. Accessed April 4, 2012.

44. Albar M. Seeking Remedy, Abstaining from Therapy and Resuscitation: An Islamic Perspective. Saudi J Kidney Dis Transpl 2007;18:629-37. 